\title{
PRODUCTIVE RESTRUCTURING IN THE AREA OF HEALTH AND OBSTETRIC NURSING
}

\author{
Juliana Amaral Prataํ, Jane Márcia Progianti², Helena Scherlowski Leal David³
}

\begin{abstract}
${ }^{1}$ Doctoral student on the Postgraduate Program in Nursing, at the Faculty of Nursing of Universidade do Estado do Rio de Janeiro (UERJ). R.N of the Municipal Health Department, Rio de Janeiro. Rio de Janeiro, Brazil. E-mail: juaprata@gmail.com

2 Ph.D. in Nursing. Associate Professor of the Department of Mother and Child Nursing, Faculty of Nursing, UERJ. Rio de Janeiro, Rio de Janeiro, Brazil. E-mail: jmprogi@uol.com.br

${ }^{3}$ Ph.D. in Public Health. Professor of the Department of Public Health Nursing, Faculty of Nursing, UERJ. Rio de Janeiro, Rio de Janeiro, Brazil. E-mail: helenalealdavid@gmail.com
\end{abstract}

\begin{abstract}
This reflection aimed to show the productive restructuring dimensions achieved in Brazilian healthcare, discussing the nexuses between this phenomenon and the work in obstetrical nursing. Its construction was based on articles about productive restructuring and health available in the Virtual Health Library, reflecting the consequences on this speciality's caregiving process. We observed that the productive restructuring in health care may be seen under the health system management and work organization viewpoints. Despite the negative impacts in the field of work, there has been an appreciation of living labor in obstetrics in a context favorable to changes in labor care, through the introduction of obstetrical nursing and implementation of health care technologies. We conclude that, besides the focus on living labor and soft technologies, such concepts comprise technological innovation, as they have changed and resignified the way of providing care, thus beginning the process of the inversion of the technological core in obstetrics. DESCRIPTORS: Obstetrical nursing. Work. Humanization of assistance. Politics. Women`s health.
\end{abstract}

\section{A REESTRUTURAÇÃO PRODUTIVA NA ÁREA DA SAÚDE E DA ENFERMAGEM OBSTÉTRICA}

RESUMO: Esta reflexão objetivou apresentar as dimensões da reestruturação produtiva concretizadas no setor da saúde brasileira, discutindo os nexos entre este fenômeno e o trabalho da enfermagem obstétrica. Sua construção baseou-se em artigos sobre reestruturação produtiva e saúde, disponíveis na Biblioteca Virtual de Saúde, refletindo os desdobramentos sobre o processo de cuidar dessa especialidade. Verificamos que a reestruturação produtiva na saúde pode ser vislumbrada, na ótica da gestão e da organização do processo de trabalho. Apesar dos impactos negativos no campo do trabalho, na obstetrícia houve a valorização do trabalho vivo living labor num contexto favorável às mudanças na assistência ao parto, por meio da inserção da enfermagem obstétrica e da implantação das tecnologias de cuidado. Concluímos que, além do enfoque no trabalho vivo e nas tecnologias leves, essas concepções constituem uma inovação tecnológica, pois modificaram e ressignificaram o modo de cuidar, iniciando o processo de inversão do núcleo tecnológico na obstetrícia.

DESCRITORES: Enfermagem obstétrica. Trabalho. Humanização da assistência. Política. Saúde da mulher.

\section{LA REESTRUCTURACIÓN PRODUCTIVA EN LA SALUD Y ENFERMERÍA OBSTÉTRICA}

RESUMEN: Esta discusión pretende presentar dimensiones de reestructuración productiva en el sector de salud en Brasil, discutiendo la relación con el trabajo de la enfermería obstétrica. Su construcción se basó en artículos sobre reestructuración productiva y salud, disponibles en la Biblioteca Virtual de Salud, reflejando el desarrollo del proceso de cuidar de esta especialidad. Verificamos que reestructuración productiva en salud se puede vislumbrar en la gerencia y la organizacíon del trabajo en salud. A pesar de los impactos negativos en el ámbito del trabajo, en obstetricia hubo apreciación del trabajo vivo en un contexto favorable a cambios en la asistencia al parto, a través de la inserción de la enfermería obstétrica e implementación de tecnologías de cuidado. Concluimos que, además de centrarse en el trabajo vivo y tecnologías livianas, estas concepciones constituyen avance tecnológico, pues modificaron y resignificaron el cuidar, iniciando el proceso de inversión del núcleo tecnológico en obstetricia.

DESCRIPTORES: Enfermería obstétrica. Trabajo. Humanización de la atención. Política. Salud de la mujer. 


\section{INTRODUCTION}

In the beginning of the 1970s, the process of transformation of capitalism led to a worldwide crisis characterized by the exhaustion of the Fordist model of production, which was expressed through the acceleration of rates of inflation, the reduction of productivity, the growth and rise of public debts, and an increase in unemployment. ${ }^{1-2}$

Fordism, as well as being an expansionist mode of production, was a model of development adopted by the capitalist societies, which viabilized the social inclusion of a large proportion of workers, both in the viewpoint of consumption as a result of increases in salary, and in citizenship rights, through the creation of the welfare state, as a result of the demands of increasingly-organized workers. ${ }^{1,3}$ From the point of view of the organization of the work processes, it was strongly supported by Frederick Taylor's so-called Theory of Scientific Management of Work, whose characteristics of segmentation of tasks, hierarchization of relationships, payments for productivity and division between the spheres of planning and undertaking of the task, among others, drove industrial production, as well as influencing the work in the services sector. ${ }^{4}$

The crisis of this pattern of accumulation of capital and organization of production represented the breaking of a social pact, creating instability and insecurity in the political, economic and social planes. ${ }^{1}$ This scenario lasted until the end of the 1970s, when neoliberal thinking conquered spaces in the developed countries and showed itself as the ideology most suited to politically supporting globalization and productive restructuring, processes which were constituted in response to the crisis of Fordism, and in a reconfiguration of the mode of capitalist accumulation. ${ }^{3}$

Neoliberalism, as a doctrine which covers economics and social philosophy, brought proposals which aim to reform the Welfare States, including containing social costs, privatizing public sector-run entities, flexibilization of the work, deregulation of the market, and globalization of the economy. Such actions, from 1970 to 1980, were strategic for curing these countries' fiscal crisis, asserting the individual responsibility, and defining the minimum state, in which health is one of the sectors directly affected. ${ }^{5}$

Although it has been consolidated in recent decades, the process of globalization was already contained in capitalism since its origin, as this means of production has in its genesis the accumulation, concentration, centralization and internationalization of capital. Hence, globalization is the expression of a new plateau of capitalism, allowing the full mobility of capital at a global level. ${ }^{6-7}$

The neoliberal advance and globalization benefited from productive restructuring, which is defined as a process which emphasizes the need for structural transformations in the ambit of production and of work, pointing to a new technological and organizational paradigm, with the adoption of new patterns of management and organization of the work. ${ }^{2}$

Flexibility is the main characteristic of productive restructuring, and is present in various perspectives: in the freeing of the productive, commercial and financial processes from any rigidity of Fordism; in the flexible automation which allows changes in the productive process according to demand and the market; and the justin-time method of management, understood as the rationalization of the work process, through the economy of the elements of production, seeking efficiency and cost reductions. ${ }^{1,4}$

Accompanying the conception of a flexible work process, the market is configured by free contracting and negotiating, with flexibilization of the working day, the pay and the social rights. On the other hand, in order to meet the new demands for multifunctionality and total quality, the workforce needs to be multiskilled and qualified, presenting initiative and involvement. ${ }^{4,8}$

This new productive pattern introduces changes in the ambit of education, with proposals involving the development of skills and competencies. As a result, through investment in education for work as a means of overcoming backwardness and poverty in Brazil, professional training was configured as key to the worker's insertion in the work..$^{3-4}$ This being the case, with a discourse of valorization of education and the training of the multi-skilled worker, with ability for abstraction and decision, the work remains subordinated to capital. $^{4}$

In this context, in spite of distinct phenomena, neoliberalism, globalization and productive restructuring are articulated with the transformations which have been occurring in the capitalism of the recent decades, as they share the ideal of flexibilization in the various sectors of society, with important reflections in health, in nursing practice in general, and, consequently, in obstetrical nursing. From the point of view of the strengthening 
of a contra-hegemonic care project, constructed by obstetrical nursing over decades, it can be ascertained that, despite the set of changes which negatively affected the world of work, a strengthening of the processes of resistance also occurred, which proposed forms which are alternatives to the biomedical model of obstetrical care. ${ }^{9}$

In the light of the above, with the aim of contributing to the debates on nursing work, offering support for understanding the productive standards in which the practices of obstetrical nursing are inserted, we propose, in this reflection, to present the dimensions of the productive restructuring implemented in the Brazilian health sector, discussing the nexuses between this phenomenon and this speciality's work.

In order to achieve such objectives, articles were captured which addressed the effects of the productive restructuring in the health sector, seeking to establish articulation with the work process of obstetrical nursing in the context of the humanization of labor and childbirth.

The database used was the Virtual Health Library, adopting the terms "productive restructuring and health". This process led to the capture of 32 articles, of which 10 dealt with reflection and the debates proposed. The route for constructing the discursive formulations was the critical reading of the material selected, the extraction of the principal ideas which supported the reflections, and analysis, based on the effects of productive restructuring in the health sector and its consequences in the process of obstetrical care.

\section{The perspectives of productive restructuring in health}

Productive restructuring in the health field can be seen both in the perspective of the management of the health system, as in the aspect of the organization of the work process in this sector.

\section{Productive restructuring in the management of the Brazilian health system}

In various regions of the world, the neoliberal ideology was in full dominion, although the consequences of its reforms on the health system are more visible in Latin America, where the efforts for the democratization of access to health faced the reduction of the role of the State. Principally in Venezuela and Brazil, in spite of the unfavorable context, the social mobilization and the mechanisms of democratic participation achieved important advances for the reform of their health systems. ${ }^{10}$

In the Brazilian case, the policy of economic adjustment, implanted since the beginning of the 1990s, deeply affected the health area. The structural reforms which accompanied the entrance of neoliberalism in Brazil were based on containing costs and decentralization through the de-responsibilization of the State in the social area. ${ }^{11-12}$

In this period, in spite of the consolidation of the Unified Health System (SUS), the need to achieve inflation goals and primary surplus caused weaknesses in this sector's financial conditions. Thus, as a result of this macroeconomic policy, there was a freezing of the SUS pay scales and the absence of expansion of investment. ${ }^{11-12}$

This panorama catalyzed the clash between conceptions on the role of the State and the standards of intervention in relation to society, promoting the appearance of new models of management and the health centers, such as the cooperatives, the temporary contracts and the social organizations, which are managed by nonState public Entities, subjected to management contracts, which are monitored and evaluated by the structure of the State Health Department. ${ }^{11,13}$

This redesign of management in the health field shows one of the perspectives of the productive restructuring, based in the flexibilization of the structures and the forms of organization of the work relationships, with the promise of debureaucratization and efficiency of public health management.

In addition to this, the deregulation of the work relations in the public sphere has led to changes in the forms of structuring of the workforce in the ambit of the SUS, with the coexistence of at least three strata of health workers: those who gained employment through open, public examinations, statutory personnel, and permanent staff; those hired under the Consolidation of Labor Laws, with varying lengths of service and without contracted status to the institution; and those contracted atypically, without any contract or labor rights. ${ }^{11,13-14}$

This flexibilization and weakening of the labor relations in health can affect the bond, the responsibility and the involvement of the professional with the system, thus compromising the quality of the services and the continuity of the actions, bearing in mind the high turnover present in this context. ${ }^{13-14}$ Furthermore, this situation 
of restructuring demonstrates the weakness of the new labor arrangements, and the vulnerability of the workers who find themselves in this new configuration of the market. ${ }^{12,14}$

This scenario has been related to the process of decentralization and privatization of management in the Brazilian health system and demonstrates the materialization of capitalism in the health field which, through mercantilization and financialization, instituted productive restructuring, with impacts on the management of the public services and the organization of the work processes in health.

\section{Productive restructuring in the organization of the work process in health}

The work process in health, conceptualized as a result of the articulation between the work object, instruments, purpose and agents, ${ }^{15}$ underwent important changes due to neoliberal thinking and productive restructuring which are also reflected in the characteristics of the analyses which take it as object.

Since the 1990s, questions have arisen which are constituted as a watershed for reflection and study on the work process in health. On one hand, the questions relate to the new forms of flexible and/or informal work, and the regulation undertaken by the State, focussing on the institutional mechanisms for management of the work; at the same time as the issues of the comprehensiveness of the care and the autonomy of the subjects shifted the focus of analysis to the dimension of interaction, involving the relationship between professional and service user, and between the professionals. ${ }^{16-17}$

In the perspective of health production, in some settings, one can perceive the valorization of living labor, which is materialized through the productive act. In other words, a human work, undertaken in the interaction of the professional with the service user and her subjectivities, and which determines the production of the care. ${ }^{16-18}$ In this process, the living labor interacts with various technologies, which direct its actions to specified assistential logic and confer meaning on the mode of production of the care.

The technologies of work and health are classified as: hard technologies, involving instruments, equipment and regulations; soft-hard technologies, considered as structured technical knowledge; and soft technologies, based in rela- tional processes. ${ }^{16}$ Hence, the predominance of the type of technology in the professional's process of work characterizes the mode of production and management of the care in the undertaking of the therapeutic project. In this regard, the technological option goes through a personal dimension and through another, linked to the institutional structure of the health services itself. ${ }^{18}$

Discussing productive restructuring in health production leads to changes in the way of producing the care, based on innovations in the productive systems of health, which are reflected in the way of producing the health products and the way of assisting and caring. ${ }^{16-18}$ In addition to this, changes in the health professionals' attitudes also point to a productive restructuring, as part of a process of reflection and subjectification which, in incorporating new attitudes creates new practices which configure new means of caring. ${ }^{19}$ One can, therefore, emphasize that, in the ambit of micropolicy, processes of micro-political and economic reconfiguration - with a view to maintaining a specified social order - do not always follow these predetermined paths, and can configure contexts which appear as contra-hegemonic proposals to the current modes of producing health and life.

Technological incorporation or changes in the productive model characterized productive restructuring, but do not necessarily entail change of the technological core of the production of care. For this phenomenon to occur, the transformations must be so deep that they change the logic of the health production, prioritizing the living labor, to the detriment of the hegemony centered on procedures, that is, dead labor. ${ }^{17-18}$

In this regard, when the changes operate on the direction of the mode of production based in soft technologies and in living labor, configuring a new model of care, it is understood that there has been a technological transition, as there has been a redefinition of the way of working in the world of health work. ${ }^{17-18}$

Based on the above, we can perceive that in the obstetrical field, a process of productive restructuring took place, which began with the valorization of living labor, in the context which was favorable to changes in childbirth assistance, although unfavorable in the perspective of the world as an emancipatory and autonomous process. Later, these transformations intensified, based on the use of soft technologies for obstetrical nursing. 


\section{The nexuses of productive restructuring with obstetrical nursing work in the context of humanization of labor and birth}

Until the mid-1980s, the biomedical paradigm was shown to be the hegemonic technological model of obstetrical practice. Allied to the growing medicalization of society, and to the development of hard technological innovations, this model transformed birth into a medical and institutionalized act. Thus, through the strong production of consultations, tests and procedures, the mode of production and management of obstetrical care was characterized by the predominance of dead labor. ${ }^{16}$

During the 1990s, however, this form of producing the care in obstetrics presented negative reflections in relation to the indiscriminate use of interventions, and resulted in an increase of rates of maternal and neonatal mortality, alarming the Brazilian authorities at that time. At the same time, the criticisms regarding the intense medicalization and medical authoritarianism in obstetrics developed from different perspectives, driving the organization of the movement for the humanization of labor and birth in our society. ${ }^{11,20}$

Accompanying the worldwide tendency of the contemporary social movements, this movement involved a variety of agents, which made the broad circulation of capital possible and the forming of circles of inter-organizational solidarity, characterizing the interaction in a network. ${ }^{21}$ In this regard, health professionals, sociologists, anthropologists, feminists, women and nongovernmental organizations mobilized around common interests, constituting the Network of Movements for the Humanization of Labor and Childbirth, which came to assert transversal issues such as: women's sexual and reproductive rights, and the valorization of the female in obstetrics, through recovering normal birth, with the minimum of interventions. ${ }^{11}$

Those involved in the struggle acted cooperatively and established articulations which resulted in greater visibility in the political field, increasing the impact of their struggles in the public sphere. ${ }^{21}$ As a result, the network's proposals became concrete actions, as the humanization of the labor and birth was incorporated into the SUS's legal and planning discourse, with the elaboration of documents and manuals which emphasized the appropriate use of the technologies, with emphasis on those considered soft.
These technologies were associated with obstetrical nursing through the publication of a legal framework, the Ministerial Ordinances $n$. $2.815 / 98$ and $169 / 98$, which favored the insertion and legitimized the work of these specialists in care for normal births in the obstetrical field. , $^{11,20,22}$

On this subject, we perceive that the beginning of productive restructuring in obstetrics occurred based on changes in the mode of production and management of the care, resulting from the humanized model of care in childbirth and the entrance of a new agent in the field, which changed the assistential logic, shifting the focus from dead labor to living labor.

In this process of changes, specialists in obstetrical nursing had an essential role in the consolidation of the productive restructuring, as they showed willingness to develop specific skills for valorization of the feminine ${ }^{20,22}$ and transformed their work process and the practice in the logic of humanization which, for this group of specialists, meant the de-medicalization of assistance with childbirth.

This meaning has been attributed to professionals' changes in attitude in the interaction with women, eliminating clinical-medical reasoning as the only alternative in the construction of the care, based on the understanding of the woman's right to choose and the possibility of offering other options for the process of giving birth. ${ }^{20}$

In the perspective of de-medicalization, specialists in obstetrical nursing developed the technologies of care, defined as techniques, procedures and knowledges used in different phases of the process of labor and birth. Thus, they are essentially soft technologies, which make up a set of structured knowledges, resulting from the practice, which are applied intentionally and with reasons, and which produce results. ${ }^{20,23}$

Obstetrical nursing care's technologies are complex and characterized as non-invasive, as they have the following attributes: to be relational, in favoring embracement and the forming of a bond with the woman in the shared construction of comprehensive care; to be catalyzing, and mobilizing the capacity existing in each woman to deal with the transformations resulting from the process of pregnancy, labor and birth, in all the dimensions; to be open, in taking into account and incorporating, in the construction of the care, the social, environmental and mystical influences, unique to each woman; to be alive, as it occurs based on interactions with the woman; to be ca- 
pable of evolving, as it is constantly renewed in each meeting, as changes appear; and to be a technology of comfort, which seeks, with the woman, to promote a pleasurable and full experience of the process of pregnancy and birth. ${ }^{23}$

Currently, the concept of non-invasion is being incorporated into the technologies of obstetrical nursing care, as professionals who are specialists in this area take on the role of supporter and understand the woman's protagonism during the process of birth, respecting her privacy and her decisions. As a result, in developing these technologies, the speciality has been highlighting the difference of its knowing-doing in the obstetrical field, and is contributing such that society can re-signify the way of assisting and caring in obstetrics.

The concepts in which the technologies of obstetrical nursing care are based, with a focus on living labor and the use of soft technologies, constitute a technological innovation, which represents a new pattern of production of care in assistance with childbirth, and which changes the way of organizing the productive process, initiating the inversion of the technological core of the care.

Based on the above, we can say that obstetrical nursing has taken on an active role in the productive restructuring of obstetrics in the context of the humanization of labor and birth, as, through the development and implementation of noninvasive technologies of care, the obstetric field is reconfigured, contributing to the technological transition in obstetrics.

\section{FINAL CONSIDERATIONS}

In Brazil, the reconfiguration of the obstetric field was intensified based on the development and implementation of obstetrical nursing's technologies of care. Beyond the focus on the living work and the use of soft technologies, there are new conceptions incorporated into this speciality's knowing-doing, which constitute a technological innovation, as they changed and re-signified the way of assisting and caring in obstetrics.

Although these transformations constituted the beginning of the process of inversion of the technological core, the technical composition of the work and the obstetrical field still present the hegemony of dead labor. There are currently changes in progress, in the public health institutions, and the context is favorable for the strengthening of the humanized model, with the effective functioning of obstetrical nursing as a strategic agent for the achievement of this process.

From the point of view of the worker's autonomy within her work process, it is clear that the practice of obstetrical nursing, dimensioned by a non-medicalizing perspective, is opposed to the tendency to heteronomy and alienation which the uncritical incorporation of hard technologies entails.

It is worth noting, however, that neoliberal thinking, far from being removed from Brazilian social and political practices, has been reconfigured in the crisis context of the mode of capitalist accumulation, which imposes new dynamics on the world of work. An example of this is the recent incorporation of the idea of the hour bank system, used in the industrial sector, as a way of ensuring that specific times of production are intensified, in this specific case, at the cost of the extension of the working day, for later compensation at times of lower productive necessity. All that is left to know is what the configurations are that more recent ways of reorganizing the work impose on the services and health sector, and, in particular, for obstetrical nursing practice.

In the light of the above, we observe in order to reflect on the different dimensions of the productive restructuring in obstetrical nursing, as, if on the one hand this process favors the occupation of spaces and strengthens this speciality's effective practice, on the other, in the perspective of the management and organization of the health system, it represents flexibilization and the weakening of the labor relations. Hence, we suggest further studies that may establish strategies so as to promote the technological transition in obstetrical nursing, taking into consideration the negative consequences of productive restructuring on its work process.

\section{REFERENCES}

1. Filgueiras LAM. Reestruturação produtiva, globalização e neoliberalismo: capitalismo e exclusão social neste final de século. In: Anais do V Encontro Nacional da Associação Brasileira de Estudos do Trabalho, 1997 Set 10-12, Rio de Janeiro(RJ): ABET, 1997. p. 895-919.

2. Gomes Serafim MT. Debate sobre a reestruturação produtiva no Brasil. RA'EGA. 2011; 21:51-77.

3. Andrade FF. Reestruturação produtiva: dos novos padrões de acumulação capitalista ao novo parâmetro de políticas sociais. Rev Urutágua. 2004 Ago-Nov; (10):1-9. 
4. Estrada JHM. La formacíon por competencias y el mundo del trabajo: de la calificación a la empleabilidad. Rev Salud Pública. 2012 Jun; 14 (Suppl 1):98-111.

5. Munhoz DB, Jesus JAL, Costa MA, Souza EM. Neoliberalismo e Estado mínimo: repercussões na atenção à saúde no Distrito Federal. Comun Ciênc Saúde. 2009 Jul-Set; 20(3):271-76.

6. Santos TS. Globalização e exclusão: a dialética da mundialização do capital. Sociologias. 2001 Jul-Dez; (6):170-98.

7. Rocha-Vidigal CB. Vidigal VG. Investimento na qualificação profissional: uma abordagem econômica sobre sua importância. Acta Scien Human Social Sci. 2012 Jan-Jun; 34 (1):41-8.

8. Bernardino MTS, Bento PEG. Reestruturação produtiva: condições de trabalho e saúde no Brasil. Cadernos Terap Ocupac UFSCar. 2002 Jan-Jun; 10(1):19-29.

9. Pereira ALF. Moura MAV. Hegemonia e contrahegemonia no processo de implantação da Casa de Parto no Rio de Janeiro. Rev Esc Enferm USP. 2009 Dez; 43(4):872-9.

10. Mahmood Q. Muntaner C. Politics, class actors, and health sector reform in Brazil and Venezuela. IUHPE - Global Health Promotion. 2013 Mar; 20(1):59-67.

11. Prata JA, Progianti JM, Pereira ALF. O contexto brasileiro de inserção das enfermeiras obstétricas na assistência ao parto humanizado. Rev Enferm UERJ. 2012 Jan-Mar; 20(1):105-10.

12. Garcia AL, Oliveira ERA, Barros EB. Qualidade de vida de professores do ensino superior na área da saúde: discurso e prática cotidiana. Cogitare Enferm. 2008 Jan-Mar; 13(1):18-24.

13. Gomez CM, Thedim-Costa SMF. Precarização do trabalho e desproteção social: desafios para a saúde coletiva. Ciên Saúde Coletiva. 1999 Jan; 4(2):411-21.

14. Flegeler DS, Guerra MA, Espindula KD, Lima RCD. O trabalho dos profissionais de saúde na estratégia saúde da família: relações complexas e laços institucionais frágeis. UFES Rev Odontol. 2008 Out-Dez; 10(4):17-23.

15. Mendes RBG. Práticas de Saúde: processos de trabalho e necessidades. São Paulo (SP): Centro de Formação dos Trabalhadores em Saúde da Secretaria Municipal da Saúde, 1992.

16. Ferreira VSC, Andrade CS, Franco TB, Merhy EE. Processo de trabalho do agente comunitário de saúde e a reestruturação produtiva. Cad Saúde Pública. 2009; 25(4):898-906.

17. Franco TB, Merhy EE. Atenção domiciliar na saúde suplementar: dispositivo da reestruturação produtiva. Ciência Saúde Coletiva. 2008 Set-Out; 13(5):1511-20.

18. Martins AM, Franco TB, Merhy EE, Feuerwerker LCM. A produção do cuidado no Programa de Atenção Domiciliar de uma cooperativa médica. Rev Saúde Coletiva. 2009; 19(2):457-74.

19. Bourdieu P. O poder simbólico. $9^{\mathrm{a}}$ ed. Rio de Janeiro (RJ): Bertrand Brasil; 2006.

20. Progianti JM, Vargens OMC. As enfermeiras obstétricas frente ao uso de tecnologias não invasivas de cuidado como estratégias na desmedicalização do parto. Esc Anna Nery Rev Enferm. 2004 Ago; 8(2):194-7.

21. Scherer-Warren I. Das mobilizações as redes de movimentos sociais. Soc Estado. 2006 Jan-Abr; 21(1):109-30.

22. Vargens OMC, Progianti JM, Silveira ACF. O significado de desmedicalização da assistência ao parto no hospital: análise da concepção de enfermeiras obstétricas. Rev Esc Enferm USP. 2008 Jun; 42(2):339-46.

23. Torres JA, Santos I, Vargens OMC. Construindo uma concepção de tecnologia de cuidado de enfermagem obstétrica: estudo sociopoético. Texto Contexto Enferm. 2008 Out-Dez; 17(4):656-64. 